\title{
Total Synthesis of $\mathrm{N}$-Acetylglucosamine-1,6-anhydro- $\mathrm{N}$ - acetylmuramylpentapeptide and Evaluation of Its Turnover by AmpD from Escherichia coli
}

\author{
Dusan Hesek, Mijoon Lee, Weilie Zhang, Bruce C. Noll, and Shahriar Mobashery \\ Department of Chemistry and Biochemistry, University of Notre Dame, Notre Dame, IN 46556 \\ Shahriar Mobashery: mobashery@nd.edu
}

\begin{abstract}
The bacterial cell wall is recycled extensively during the course of cell growth. The first recycling event involves the catalytic action of the lytic transglycosylase enzymes, which produce an uncommon 1,6-anhydropyranose moiety during separation of the muramyl residues from the peptidoglycan, the major constituent of the cell wall. This product, an $N$-acetyl- $\beta$-D-glucosamine$(1 \rightarrow 4)-1,6$-anhydro- $N$-acetyl- $\beta$-D-muramylpeptide, is either internalized to initiate the recycling process or diffuses into the milieu to cause stimulation of the pro-inflammatory responses by the host. We report the total syntheses of $N$-acetyl- $\beta$-d-glucosamine- $(1 \rightarrow 4)-1,6$-anhydro- $N$-acetyl- $\beta$-Dmuramyl-L-Ala- $\gamma$-D-Glu-meso-DAP-D-Ala-D-Ala (compound $\mathbf{1}$, the product of lytic transglycosylase action on the cell wall of Gram-negative bacteria) and $N$-acetyl- $\beta$-D-glucosamine-( $1 \rightarrow 4)-1,6$ anhydro- $N$-acetyl- $\beta$-D-muramyl-L-Ala- $\gamma$-D-Glu-L-Lys-D-Ala-d-Ala (compound 2 , from lytic transglycosylase action on the cell wall of Gram-positive bacteria). The syntheses were accomplished in 15 linear steps. Compound $\mathbf{1}$ is shown to be a substrate of the AmpD enzyme of the Gram-negative bacterium Escherichia coli, an enzyme that removes the peptide from the disaccharide scaffold in the early cytoplasmic phase of cell wall turnover.
\end{abstract}

The polymeric bacterial cell wall encases the entire microorganism. ${ }^{1-3}$ As the health of the cell wall is critical for survival of the bacterium, the cell wall itself and its associated biosynthetic machinery are targets of antibiotics. ${ }^{4,5}$ Largely because of its complexity, many of the biosynthetic and regulatory steps governing the integrity of the cell wall are poorly understood. A major impediment to the study of the biochemical events involving the cell wall is the unavailability of the structurally complex molecules involved in its biosynthesis and homeostasis.

Peptidoglycan, the major constituent of cell wall, is a repeating unit of $N$-acetylglucosamine (NAG) and $N$-acetylmuramic acid (NAM). A stem peptide, typically a pentapeptide, is appended to the NAM unit. The NAG-NAM unit is polymerized by the action of transglycosylases to generate the glycan strand of the peptidoglycan, which in turn experiences cross-linking to a neighboring strand to generate the mature cell wall. ${ }^{6}$ It is a little known facet of cell wall events that in the course of bacterial growth, as much as $60 \%$ of the parental peptidoglycan may be recycled. ${ }^{7,8}$ The economy of existence drives much of the need for cell wall recycling, but these events have also evolved to facilitate a resistance response to certain antibiotics. 9,10

Correspondence to: Shahriar Mobashery, mobashery@nd.edu.

Supporting Information Available. Experimental procedures, compound characterization data, including copies of 1D NMR spectra $\left({ }^{1} \mathrm{H},{ }^{13} \mathrm{C}\right.$ NMR, and DEPT) and 2D NMR spectra (H-H COSY and H-C HETCOR) of synthesized compounds, and X-ray data of compounds $4 \mathbf{4 a}, \mathbf{5}, \mathbf{6 , 8}, 11$ and $30(\mathrm{CIF})$. This material is available free of charge via the Internet at http://pubs.acs.org. 
The initiation of the recycling events commences by degradation of the polymeric cell wall. A key step in this degradation is glycan strand cleavage, catalyzed by the family of lytic transglycosylases. ${ }^{11-13}$ The mechanism of these enzymes is suggested to involve general acid activation of the NAM-NAG glycosidic bond, facilitating the formation of a reactive oxocarbenium species, which undergoes intramolecular trapping by the C-6 hydroxyl of the NAM saccharide to give the $N$-acetylglucosamine-1,6-anhydro- $N$-acetylmuramyl moiety as products. Compounds $\mathbf{1}$ is obtained from the Gram-negative cell wall, and compound $\mathbf{2}$ is obtained from the Gram-positive cell wall (Figure 1). This reaction fragments the glycan strands of the cell wall, releasing a disaccharide unit into the milieu after each turnover. The presence of the 1,6-anhydro- $N$-acetylmuramyl moiety in the cell wall was reported for the first time in 1975 by Taylor et al. ${ }^{14}$ In E. coli, $\mathbf{1}$ is transported into the cytoplasm by the integral membrane protein AmpG to serve as a substrate for cytoplasmic recycling. ${ }^{15}$ Alternatively, compound $\mathbf{1}$ diffuses out of the bacterium. Structures such as $\mathbf{1}$ are recognized by eukaryotic peptidoglycan-recognition proteins, eliciting pro-inflammatory responses by the host. ${ }^{16-18}$ Related compounds have been implicated as having immune response modulant, ${ }^{19}$ somogen,${ }^{20-22}$ hypotensive and diuretic activities. ${ }^{23}$

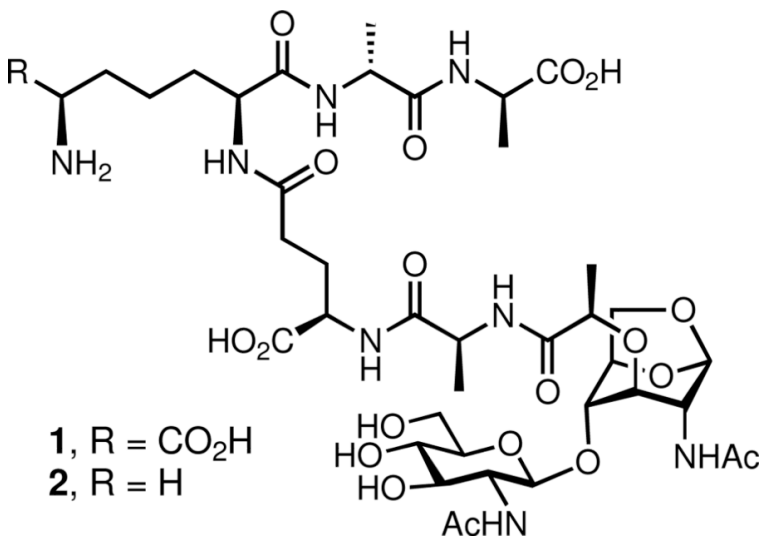

Once internalized, compound $\mathbf{1}$ is degraded in a number of steps to components that are ultimately reused for de novo synthesis of cell wall. The details of these enzymic steps are not well understood, in large measure because of the lack of availability of cell wall samples for their investigations. For example, compound $\mathbf{1}$ could serve as substrate for either AmpD or NagZ (Figure 1). The former is an amidase that would degrade the peptide from the disaccharide structure, whereas the latter is believed to be a glycosidase that would hydrolyze the glycosidic bond of $\mathbf{1}$.

Both the lack of quantity and uncertain quality have been obstacles to research on the biological roles of $\mathbf{1}$ as a bacterial metabolite. To address this need, we describe herein the total syntheses of compounds $\mathbf{1}$ and $\mathbf{2}$. The syntheses produce tens of milligrams of each, and are amenable to scale up. The availability of these compounds addresses a critical need for investigation of the biology of inflammation during bacterial infections, as well as the elucidation of the processes involved in cell wall recycling. Toward these objectives, our synthesis of $\mathbf{1}$ has allowed its evaluation as a substrate for $\mathrm{AmpD}$, the aforementioned enzyme implicated in the early cytoplasmic events for turnover of $\mathbf{1}$ in Gram-negative bacteria. We report herein the competence of compound $\mathbf{1}$ as a substrate for AmpD, and the kinetic parameters for AmpD-catalyzed hydrolysis of the amide bond between the ${ }_{\mathrm{D}}$-Lactate and ${ }_{\mathrm{L}}$-Ala components of the peptide stem of $\mathbf{1}$. 


\section{Results and Discussion}

The class of compounds exemplified by $\mathbf{1}$ and $\mathbf{2}$ has largely been accessed by enzymatic degradation of bacterial cell wall. The product(s) obtained from this degradation have uncertain quality and are obtained in small amounts. Total synthesis addresses both limitations. Taking advantage of literature precedent from other labs $22,24,25$ as well as our own ${ }^{26}$ we have devised a practical synthesis of these cell wall fragments. The key features of our strategy are (1) a TfOH-mediated $\beta$-1,4-glycosylation using a trichloroacetimidate glycosyl donor, (2) the coupling of the protected pentapeptide and the protected disaccharide at the final stages of the synthesis and (3) the use of catalytic hydrogenation for final global deprotection. Several specific obstacles to the syntheses of this molecular class existed at the outset. These obstacles included a method for formation of the anhydrosugar, and identification of efficacious choices for the glycosyl donor and acceptor pair for construction of the GlcNAc- $\beta-(1 \rightarrow 4)$-anhMurNAc glycosidic bond. While our solution to this problem used a trichloroacetimidate as the glycosyl donor, related examples from the literature have employed AgOTf-catalyzed Koenigs-Knorr glycosylation. ${ }^{22,} 27$ It is also worth mentioning that the 1,6-anhydrosugar moiety has been used in syntheses as a means of simultaneous protection of the hydroxy groups at C-1 and C- 6 . This protection scheme takes advantage of the strained 1,6-anhydro system to undergo ring opening under mild acidic conditions after chemistry is performed elsewhere on the system. ${ }^{27-29}$ However, since the targets of our syntheses have the 1,6-anhydropyranose as a structural component, its intrinsic acid sensitivity limited the synthetic options throughout the synthesis.

Two parallel approaches were examined for the synthesis of the 1,6-anhydromuramic acid, ultimately leading to 7 as a key intermediate (Scheme 1). One approach was $O$-benzyl protection of the C-4 hydroxyl, followed by formation of the anhydropyranose ring. The second approach was formation of the anhydropyranose ring first, followed by benzylation of the C-4 hydroxyl. Evaluation of the former approached commenced with bis-silyl glucal $\mathbf{3}$, prepared by literature methods. ${ }^{30,31} \mathrm{O}$-Benzyl protection of $\mathbf{3}$ was attempted using $\mathrm{NaH}$ and $\mathrm{BnBr}$ in anhydrous DMF, also a literature method. ${ }^{30}$ Although these reagents are standard for $O$-alkylation, an unexpected and regioselective silyl deprotection gave $\mathbf{4 a}$ in $65 \%$ yield, along with the desired product $\mathbf{4 b}$ in $20 \%$ yield. The structure of $\mathbf{4 a}$ was assigned by X-ray analysis (Scheme 1). The interesting regioselective desilylation likely involves an anionic species, generated from DMF as a side reaction mediated by NaH ${ }^{32}$ Although silyl migration has been observed previously in chemistry involving five- or six-membered saccharides, ${ }^{33-37}$ cyclodextrin ${ }^{38}$ and aromatic derivatives, ${ }^{39,40}$ to our knowledge regioselective monodesilylation is unprecedented. By merely switching the solvent from anhydrous DMF to anhydrous THF, the compound $\mathbf{4 b}$ was obtained as the major product in a yield of $89 \%$.

The TBAF-mediated desilylation of $\mathbf{4 b}$ proceeded in $90 \%$ yield. The structure of $4-O$ benzyl-D-glucal (5) was confirmed by X-ray crystallography. The ring closure of 5 to give $\mathbf{6}$ was carried out by a literature method (bis(tributyltin)oxide, iodine in the presence of propylene oxide). ${ }^{41}$ This reaction introduces considerable ring strain due to the bicyclic nature of the scaffolding, and the all-axial arrangement of the ring substituents. Because of the unusual nature of this reaction, unambiguous verification of the reaction product was required. The crystal structure of 6 confirmed a pyranose ${ }^{1} C_{4}$ conformation for the 1,6anhydropyranose (instead of the typical ${ }^{4} C_{1}$ chair conformation of glucopyranose) having all-axial substituents. Compound 6 was converted by $\mathrm{K}_{2} \mathrm{CO}_{3}$ to the known compound $7^{42}$ in $85 \%$ isolated yield.

We also attempted to synthesize 7 from $9,{ }^{41,43}$ which we prepared directly from D-glucal using the $\left(\mathrm{Bu}_{3} \mathrm{Sn}\right)_{2} \mathrm{O}, \mathrm{I}_{2}$, propylene oxide reagent combination. Formation of epoxide $\mathbf{1 0}$ 
(one of the targeted glycosyl acceptors) occurred cleanly in $92 \%$ isolated yield using $\mathrm{Ag}_{2} \mathrm{CO}_{3}$ as the base. The choice of silver carbonate-as opposed to potassium carbonate, for example - was deliberate. The high affinity of silver for the halide is presumably the driving force for the reaction, as the use of potassium carbonate in the same reaction was considerably less clean. Attempted benzylation of the axial hydroxyl group of $\mathbf{1 0}$ under standard conditions did not produce 7 , as was expected. ${ }^{44}$ Rather, we obtained a product in $85 \%$ yield having a different ${ }^{1} \mathrm{H}$ NMR spectrum than 7 but the same molecular mass as 7 . Analysis of a crystal of this reaction product revealed its structure as that shown for $\mathbf{1 1}$ (Schemes 1 and 2). This outcome can be explained by a facile base-catalyzed Payne rearrangement of $\mathbf{1 0}$ to $\mathbf{1 0 a}$, which disposes the equatorial C-2 oxygen to benzylation, as studied by Černý and coworkers. ${ }^{45}$ The rearrangement from mannose derivative $\mathbf{1 0}$ to $\mathbf{1 1}$ is known, but without analysis of the product. ${ }^{46}$ Otherwise, compound $\mathbf{1 1}$ is generally prepared from altrose derivative 10a in the presence of $\mathrm{NaH}$ and catalytic $n$-Bu 4 NI in THF. ${ }^{47}, 48$ This rearrangement exemplifies the challenge to the choice of epoxide $\mathbf{1 0}$ as a synthetic intermediate, as was previously discussed. ${ }^{44,45}$ Our silver-carbonate-promoted reaction appears to be advantageous over other reagents for this particular transformation, as the reaction proceeds cleanly. Additionally, we could prepare $\mathbf{7}$ from compound $\mathbf{1 0}$ under acidic condition (Scheme 2) by employing benzyl 2,2,2-trichloroacetimidate in the presence of $\mathrm{BF}_{3} \cdot \mathrm{OEt}_{2}$, a reaction that does not suffer the shortcomings of the Payne rearrangement.

With compound 7 in hand, we were poised for the installation of the nitrogen at C-2 needed for eventual elaboration to the 2-acetamido group. In this vein, treatment of 7 with azidotrimethylsilane and $\mathrm{BF}_{3} \cdot \mathrm{Et}_{2} \mathrm{O}$ at $45^{\circ} \mathrm{C}$ gave regioselective ring opening to produce 8 in $70 \%$ yield (Scheme 1). This reaction achieves regioselective installation of azido group at C-2 in excellent yield and under very mild reaction conditions. In our hands attempts at direct aminolysis of $\mathbf{7}$ using methanolic ammonia, or using sodium azide and ammonium chloride (in DMF at $140^{\circ} \mathrm{C}$ ) both failed, however, success with these reactions have been reported by others. ${ }^{49}$ An alternative approach to 8 using reaction of iodide 6 with excess teteramethylguanidium azide in DMF $\left(120^{\circ} \mathrm{C}, 3\right.$ days $)$ is known from the literature..$^{25}$ The structure of azide $\mathbf{8}$ was confirmed by X-ray crystallography. Short exposure of azide $\mathbf{8}$ to standard hydrogenation conditions $(10 \% w / w 5 \% \mathrm{Pd} / \mathrm{C}, \mathrm{MeOH}, 1 \mathrm{~h}$ at $\mathrm{rt})$ provided the desired amine without loss of the benzyl ether at C-4. Acetylation (both of the amine and the hydroxyl at C-3), debenzylation at C-4 under more strenuous conditions (15\% w/w of $10 \%$ $\mathrm{Pd} / \mathrm{C}, \mathrm{MeOH}, 4 \mathrm{~h}$ at $55{ }^{\circ} \mathrm{C}$ ) provided the glycosyl acceptor $13 .{ }^{50}$ Azide 8 also served as the pivotal intermediate to glycosyl acceptor 14 . The lactate moiety was introduced to the C-3 alcohol of $\mathbf{8}$ as described by Paulsen $e t$ al. ${ }^{22}$ Reduction of the azide to the amine, $N$ acetylation, and removal of the benzyl group at C-4 gave the known compound $\mathbf{1 4} .^{22,25,31}$

Identification of a viable glycosylation method proved to be as difficult as we initially anticipated. We required a Lewis acid that would preserve the anhydropyranose yet promote glycosylation and coincide with a practical post-glycosylation strategy to the synthetic targets. Successive evaluation of different donor and acceptor permutations, using four different glycosyl donors (oxazoline 15, and the three trichloroacetimidates 16, 17 and 18) proven efficacious for construction of the required $\beta$-1,4-glycosidic linkage, $26,33,50-52$ with three different acceptors $(\mathbf{1 0}, \mathbf{1 3}$, and 14), was undertaken. 


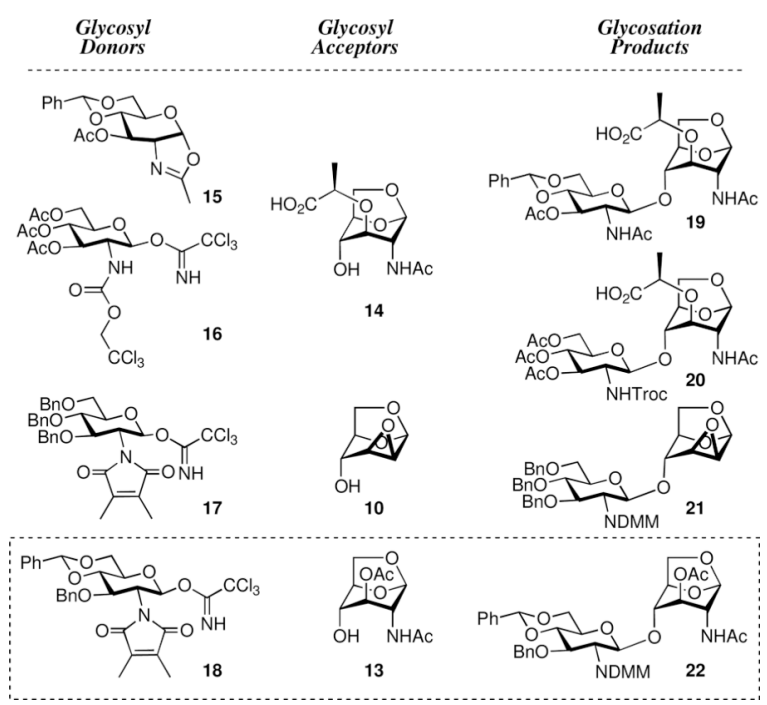

We first examined glycosylation of oxazoline $\mathbf{1 5}^{53,54}$ and 1,6-anhydromuramic acid 14, which would provide an advantageous post-glycosylation reaction sequence. Unfortunately, this pairing resulted in competitive loss of the benzylidene upon $\mathrm{BF}_{3} \cdot \mathrm{Et}_{2} \mathrm{O}$ activation of oxazoline 15. Our next evaluations used catalytic amount of TfOH activation of the trichloroacetimidates glycosyl donors. While acceptable yields were obtained, the postglycosylation steps were problematic. Trichloroacetimidate $\mathbf{1 6}^{55}$ reacted not only with the 4$\mathrm{OH}$ in $\mathbf{1 4}$ to give the desired product (20), but also with the lactyl moiety to give the ester $\mathbf{2 3}$ in 2:1 ratio (Scheme 3). Moreover, the properties of the Troc-protected disaccharides were unfavorable, as some had poor solubility and others gave a viscous gel in various solvents.

We observed unusual side reactions during the preparation of compound 17. $O$-Benzylation of glucosamine derivative $\mathbf{2 4}^{56}$ (Scheme 3 ) using $\mathrm{BnBr}$ and $\mathrm{NaH}$ in acetonitrile gave a low yield of the product 25 , as a result of an unusual side reaction involving reaction of the $\mathrm{NaH}$ and $\mathrm{BnBr}$ with acetonitrile to form 26a, 26b, and $\mathbf{2 6} \mathbf{c}$ that is described eleswhere. ${ }^{32}$ Treatment of tribenzyl 25 with TBAF followed by reaction with $\mathrm{Cl}_{3} \mathrm{CCN}$ and DBU gave the trichloroacetimidate. Glycosylation of epoxide acceptor 10 with the DMM-glucosamine donor 17 using $\mathrm{TfOH}$ as a promoter proceeded smoothly in $85 \%$ yield to provide the disaccharide 21. However, subsequent introduction of azide to $\mathrm{C}-2$ was problematic. The reaction products included not only the 2-azido $\mathbf{2 8} \mathbf{a}$ and 3-azido $\mathbf{2 8 b}$ isomers, but the glycosyl azide 27 as well. This latter reaction was due to glycosyl bond cleavage and introduction of azide at $\mathrm{C}-1$ position, mediated by $\mathrm{BF}_{3} \cdot \mathrm{Et}_{2} \mathrm{O}$ and azidotrimethylsilane. When tetraacetyl glucosamine $\mathbf{2 9}^{56}$ was subjected to the same condition $\left(\mathrm{Me}_{3} \mathrm{SiN}_{3}, \mathrm{BF}_{3} \cdot \mathrm{OEt}_{2}\right)$, tris- $O$-acetyl glucosyl azide $\mathbf{3 0}$ was obtained in $80 \%$ yield. The identity of $\mathbf{3 0}$ was unequivocally proven by its X-ray structure (Scheme 3 ). Synthesis of peracetylated glycopyranosyl azides from by nucleophilic displacement upon glycopyranosyl halides or glycopyranose peracetates is well known. ${ }^{57}$

Finally, initial experiments on coupling of $\mathbf{1 3}$ and $\mathbf{1 8}{ }^{58}$ were promising. Following reaction optimization using $\mathrm{TfOH}$ as a promoter, disaccharide $\mathbf{2 2}$ was isolated in a satisfactory yield of 75\% (Scheme 4). The DMM and the $O$-acetyl groups of $\mathbf{2 2}$ were removed by manipulation of the $\mathrm{pH}$ of the reaction ( $\mathrm{pH} 10-11$ using aq $\mathrm{NaOH}$ for $3 \mathrm{~h}$, followed by the addition of $\mathrm{HCl}$ to $\mathrm{pH} 3$ for $10 \mathrm{~h}$ ). The resultant free amine and the 3-OH were acetylated to give 31. Selective removal of the acetyl group at C-3 of $\mathbf{3 1}$ allowed introduction of the lactate moiety using $(S)$-2-chloropropionic acid in the presence of $\mathrm{NaH}$ in $48 \%$ yield over the two steps from 31, giving key intermediate 33. Compound $\mathbf{3 3}$ has the requisite structural scaffolding for the desired target by being poised to receive the peptide at the lactyl moiety. 
As both peptides 34 (diaminopimelate-based) and peptide 35 (lysine-based) are high-value intermediates, a number of peptide coupling procedures were tried on small scale. The culmination of this trial-and-error was the successful activation of the lactyl carboxylic acid as an $N$-hydroxysuccinimide ester in situ, which was allowed to react with the free-base form of the pentapeptide $\mathbf{3 4}$ to yield the desired protected compound $\mathbf{3 6}$ in $75 \%$ yield. Twostep global deprotection, using acetic acid followed by catalytic hydrogenation $(20 \% \mathrm{w} / \mathrm{w}$ of $10 \% \mathrm{Pd} / \mathrm{C}, \mathrm{MeOH}, 3 \mathrm{~h}, 50{ }^{\circ} \mathrm{C}$ ), gave target compound 1 in $66 \%$ yield. A similar set of reactions using the lysine-based peptide $\mathbf{3 5}$ produced compound $\mathbf{2}$ in similar yield.

In this report, we have disclosed a convenient method for the preparation of the product of cell wall degradation by lytic transglycosylases, compounds $\mathbf{1}$ and $\mathbf{2}$. Our synthesis has benefited from the precedent in the literature on construction of the 1,6-anhydropyranose system. Yet, methodology from our own lab allowed facile adaptation of some of the earlier methods that did not work well in our hands. Sugar chemistry is a special area of synthetic chemistry, which is highly nuanced in that it has its own unique difficulties. The methodology that we disclosed herein should make the biological studies of these systems more accessible. We add that the pioneering work from the Paulsen and Fukase labs have set a strong foundation to these systems. Paulsen and coworkers constructed the critical core anhydro-containing disaccharide using AgOTf-mediated Koenigs-Knorr in their synthesis of $\beta$-р- $N$-acetylglucosamine-( $1 \rightarrow 4)-1,6$-anhydro- $\beta$-р- $N$-acetylmuramyl-L-Ala- $\gamma$-D-Gln. ${ }^{22}$ While this manuscript was in review, Fukases and coworkers reported the first synthesis of the related tracheal cytotoxin using glycosylation of a Troc-protected glucosamine trichloroimidate and the ethyl ester of $N$-Troc-1,6-anhydromuramic acid. ${ }^{24}$ These methods and ours complement each other.

As indicated earlier, the availability of these compounds will be a boon to the investigations of the pertinent biological systems. In this vein, we evaluated the competence of $\mathbf{1}$ as a substrate for the AmpD enzyme of Escherichia coli. Compound $\mathbf{1}$ is indeed recognized as a substrate, undergoing hydrolytic cleavage $\left(k_{\mathrm{cat}}\right.$ of $0.4 \pm 0.1 \mathrm{~s}^{-1}$ and $K_{\mathrm{m}}$ of $1760 \pm 210 \mu \mathrm{M}$ ) at the expected position within its peptide stem. The time course for this reaction was evaluated by HPLC and the identities of the reaction products were verified by MS (Figure 2).

Compound 1 was synthesized in 15 sequential steps (excluding the preparation of the protected peptide) in $3 \%$ overall yield. Its availability will stimulate investigations of the complex processes of cell wall recycling, expression of antibiotic resistance enzymes, and the human immune response to bacterial infection.

\section{Supplementary Material}

Refer to Web version on PubMed Central for supplementary material.

\section{Acknowledgments}

This work was supported by the National Institutes of Health (GM61629).

\section{REFERENCES}

1. Coyette J, van der Ende A. FEMS Microbiol. Rev. 2008; 32:147-148. [PubMed: 18291012]

2. Höltje, JV. Cell Walls Bacterial. In: Schaechter, M., editor. Desk Encyclopedia of Microbiology. San Diego, London: Elsevier Academic Press; 2004. p. 239-250.

3. Suvorov, M.; Fisher, JF.; Mobashery, S. Bacterial Cell Wall: Morphology and Biochemistry. In: Goldman, E.; Green, LH., editors. Practical Handbook of Microbiology. 2nd ed.. CRC Press; 2008. p. $153-183$. 
4. Silver LL. Biochem. Pharmacol. 2006; 71:996-1005. [PubMed: 16290173]

5. Van Bambeke F, Mingeot-Leclercq MP, Struelens MJ, Tulkens PM. Trends Pharmacol. Sci. 2008; 29:124-134. [PubMed: 18262289]

6. Vollmer W, Höltje JV. J. Bacteriol. 2004; 186:5978-5987. [PubMed: 15342566]

7. de Pedro MA, Donachie WD, Höltje JV, Schwarz H. J. Bacteriol. 2001; 183:4115-4126. [PubMed: 11418550]

8. Park JT, Uehara T. Microbiol. Mol. Biol. Rev. 2008; 72:211-227. [PubMed: 18535144]

9. Wiedemann B, Pfeifle D, Wiegand I, Janas E. Drug Resist. Updat. 1998; 1:223-226. [PubMed: 16904404]

10. Jacobs C, Frere JM, Normark S. Cell. 1997; 88:823-832. [PubMed: 9118225]

11. Scheurwater E, Reid CW, Clarke AJ. Int. J. Biochem. Cell Biol. 2008; 40:586-591. [PubMed: 17468031]

12. Scheurwater EM, Clarke AJ. J. Biol. Chem. 2008; 283:8363-8373. [PubMed: 18234673]

13. Suvorov M, Lee M, Hesek D, Boggess B, Mobashery S. J. Am. Chem. Soc. 2008; 130:1187811879. [PubMed: 18700763]

14. Taylor A, Das BC, Vanheijenoort J. Eur. J. Biochem. 1975; 53:47-54.

15. Cheng QM, Park JT. J. Bacteriol. 2002; 184:6434-6436. [PubMed: 12426329]

16. Chang CI, Chelliah Y, Borek D, Mengin-Lecreulx D, Deisenhofer J. Science. 2006; 311:17611764. [PubMed: 16556841]

17. Cloud-Hansen KA, Peterson SB, Stabb EV, Goldman WE, McFall-Ngai MJ, Handelsman J. Nat. Rev. Microbiol. 2006; 4:710-716. [PubMed: 16894338]

18. Kohler PL, Cloud KA, Hackett KT, Beck ET, Dillard JP. Microbiology. 2005; 151:3081-3088. [PubMed: 16151218]

19. Traub S, Kubasch N, Morath S, Kresse M, Hartung T, Schmidt RR, Hermann C. J. Biol. Chem. 2004; 279:8694-8700. [PubMed: 14668350]

20. Krueger JM, Karnovsky ML, Martin SA, Pappenheimer JR, Walter J, Biemann K. J. Biol. Chem. 1984; 259:12659-12662. [PubMed: 6490637]

21. Krueger JM, Rosenthal RS, Martin SA, Walter J, Davenne D, Shoham S, Kubillus SL, Biemann K. Brain Res. 1987; 403:249-257. [PubMed: 3103865]

22. Paulsen H, Himpkamp P, Peters T. Liebigs Ann. Chem. 1986:664-674.

23. Watanabe K, Tanaka R, Sakurai H, Iguchi K, Yamada Y, Hsu CS, Sakuma C, Kikuchi H, Shibayama H, Kawai T. Chem. Pharm. Bull. 2007; 55:780-783. [PubMed: 17473468]

24. Kawasaki A, Karasudani Y, Otsuka Y, Hasegawa M, Inohara N, Fujimoto Y, Fukase K. Chem. Eur. J. 2008; 14:10318-10330. [PubMed: 18830984]

25. Kubasch N, Schmidt RR. Eur. J. Org. Chem. 2002:2710-2726.

26. Hesek D, Lee M, Morio KI, Mobashery S. J. Org. Chem. 2004; 69:2137-2146. [PubMed: 15058963]

27. Merser C, Sinaÿ P. Tetrahedron Lett. 1973; 14:1029-1032.

28. Ganguli ARS, Coward JK. Tetrahedron-Asymmetry. 2005; 16:411-424.

29. Krohn K, Gehle D, Flörke U. Eur. J. Org. Chem. 2005:2841-2848.

30. Bartolozzi A, Pacciani S, Benvenuti C, Cacciarini M, Liguori F, Menichetti S, Nativi C. J. Org. Chem. 2003; 68:8529-8533. [PubMed: 14575481]

31. Kinzy W, Schmidt RR. Tetrahedron Lett. 1987; 28:1981-1984.

32. Hesek D, Lee M, Noll BC, Fisher JF, Mobashery S. J. Org. Chem. Article ASAP.

33. Banoub J, Boullanger P, Lafont D. Chem. Rev. 1992; 92:1167-1195.

34. Furegati S, White AJP, Miller AD. Synlett. 2005:2385-2387.

35. Tsubouchi A, Onishi K, Takeda T. J. Am. Chem. Soc. 2006; 128:14268-14269. [PubMed: 17076495]

36. Yamazaki T, Mizutani K, Kitazume T. J. Org. Chem. 1993; 58:4346-4359.

37. Yoon S. J. Korean Chem. Soc. 2002; 46:590-594.

38. Teranishi K, Ueno F. Tetrahedron Lett. 2003; 44:4843-4848. 
39. Moser WH, Sun L, Huffman JC. Org. Lett. 2001; 3:3389-3391. [PubMed: 11594841]

40. Sole S, Gornitzka H, Guerret O, Bertrand G. J. Am. Chem. Soc. 1998; 120:9100-9101.

41. Tailler D, Jacquinet JC, Noirot AM, Beau JM. J. Chem. Soc. Perkin Trans. 1. 1992:3163-3164.

42. Trnka T, Černý M. Collect. Czech. Chem. Commun. 1971; 36:2216-2225.

43. Czernecki S, Leteux C, Veyrières A. Tetrahedron Lett. 1992; 33:221.

44. Xue J, Guo ZW. Tetrahedron Lett. 2001; 42:6487-6489.

45. Černý M, Pacák J, Staněk J. Collect. Czech. Chem. Commun. 1965; 30:1151-1157.

46. Sasaki M, Koike T, Sakai R, Tachibana K. Tetrahedron Lett. 2000; 41:3923-3926.

47. Krintel SL, Jiménez-Barbero J, Skrydstrup T. Tetrahedron Lett. 1999; 40:7565-7568.

48. Mikkelsen LM, Krintel SL, Jiménez-Barbero J, Skrydstrup T. J. Org. Chem. 2002; 67:6297-6308. [PubMed: 12201747]

49. Paulsen H, Koebernick H, Stenzel W, Koll P. Tetrahedron Lett. 1975:1493-1494.

50. Oguri S, Ishihara H, Tejima S. Chem. Pharm. Bull. 1980; 28:35-41.

51. El Ashry ESH, Aly MRE. Pure Appl. Chem. 2007; 79:2229-2242.

52. Inamura S, Fukase K, Kusumoto S. Tetrahedron Lett. 2001; 42:7613-7616.

53. Srivastava VK. Carbohydr. Res. 1982; 103:286-292.

54. Yonehara K, Hashizume T, Mori K, Ohe K, Uemura S. J. Org. Chem. 1999; 64:9374-9380.

55. Dullenkopf W, Castro-Palomino JC, Manzoni L, Schmidt RR. Carbohydr. Res. 1996; 296:135147. [PubMed: 9008845]

56. Aly MRE, Castro-Palomino JC, Ibrahim ESI, El-Ashry ESH, Schmidt RR. Eur. J. Org. Chem. 1998:2305-2316.

57. Györgydeák Z, Szilágyi L, Paulsen H. J. Carbohydr. Chem. 1993; 12:139-163.

58. Hesek D, Suvorov M, Morio K, Lee M, Brown S, Vakulenko SB, Mobashery S. J. Org. Chem. 2004; 69:778-784. [PubMed: 14750804] 

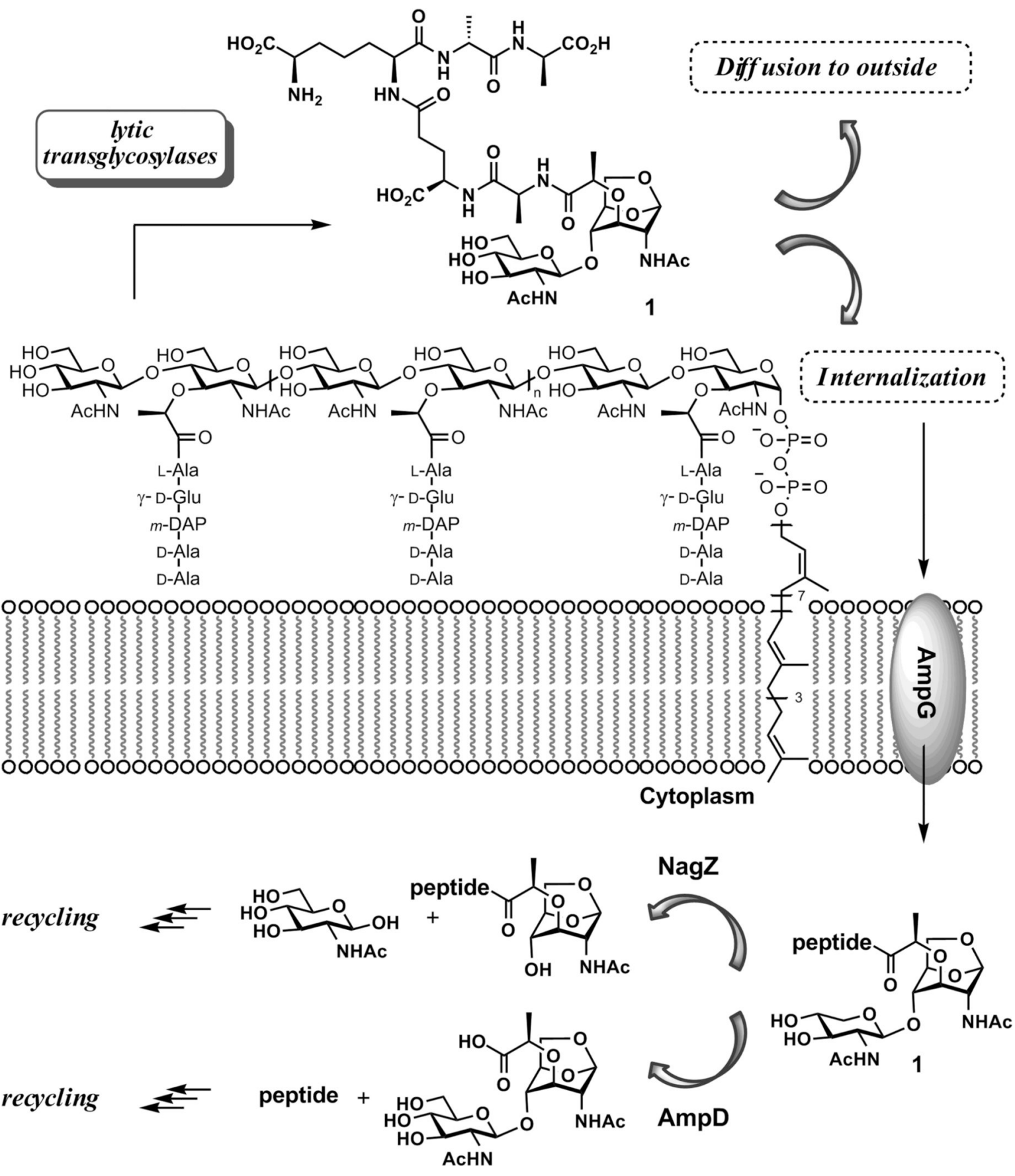

Figure 1.

The fragmentation of cell wall by lytic transglycosylases. The minimal fragmented product is internalized by AmpG for recycling. 


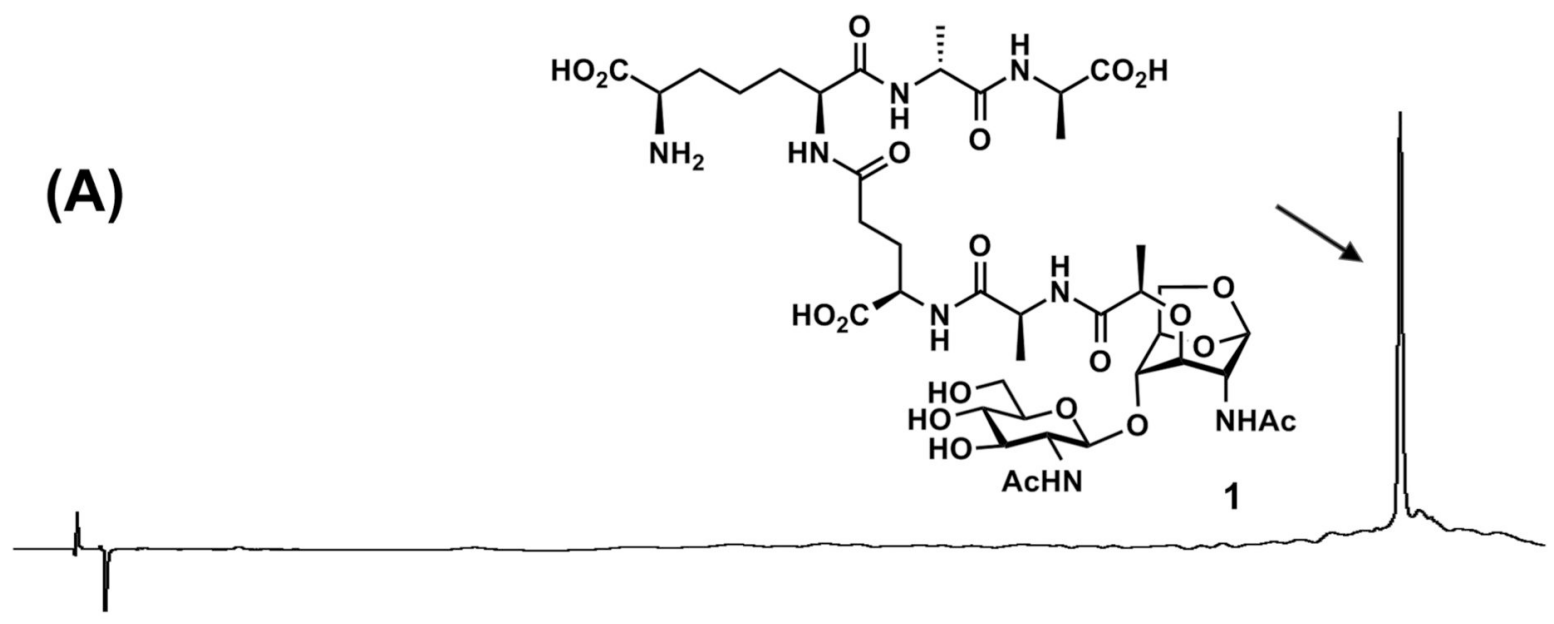

(B)

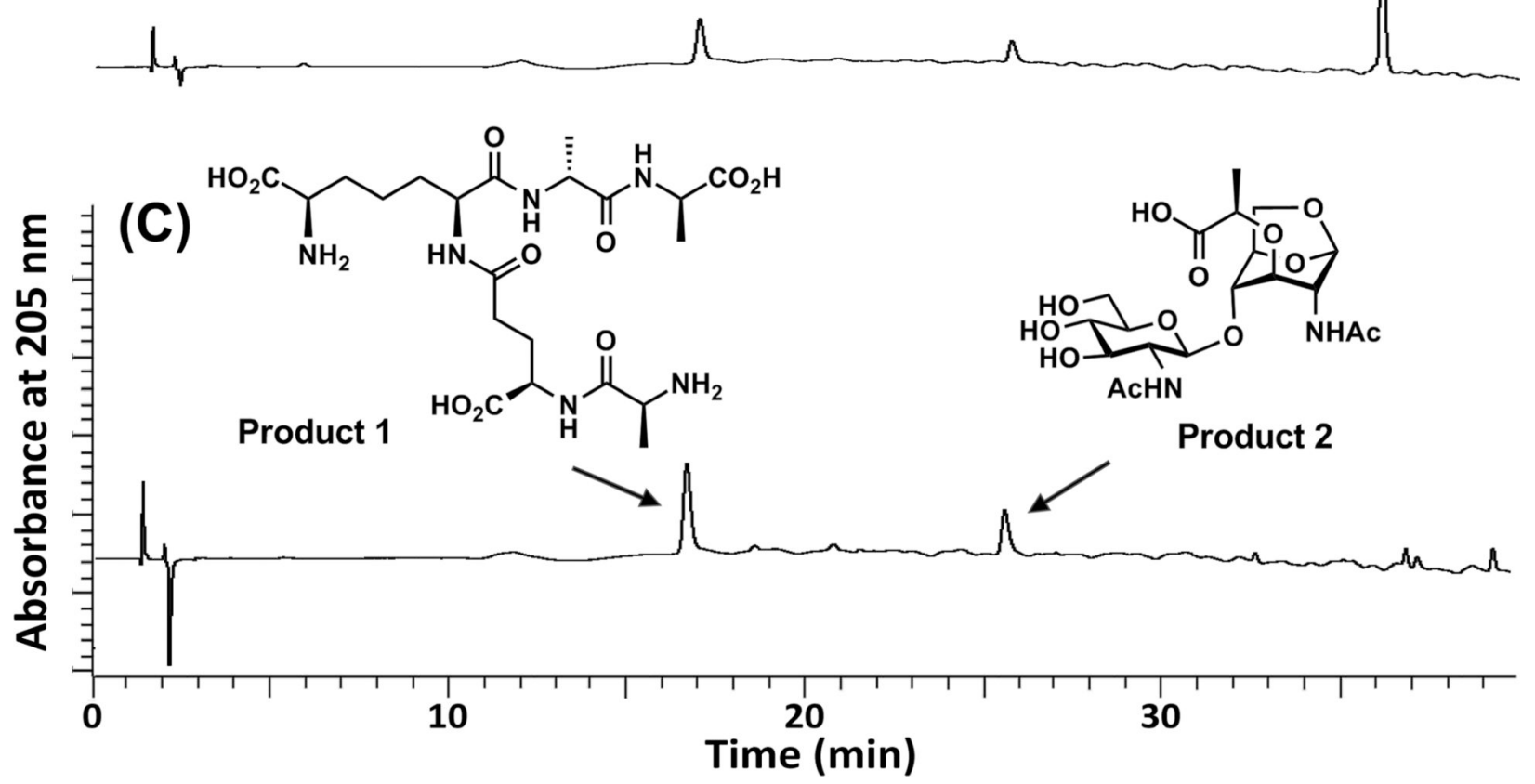

Figure 2.

The AmpD reaction with compound 1. (A) The single peak is compound 1 at time zero. (B) Compound 1 was hydrolyzed by AmpD, and the two products were formed (retention time at $16.5 \mathrm{~min}$ and $25.5 \mathrm{~min}$ ) at $60 \mathrm{~min}$ of incubation. (C) The AmpD reaction mixture at $3 \mathrm{~h}$. The two new peaks correspond to product $\mathbf{1}$ (pentapeptide) and product $\mathbf{2}$ (GlcNAcanhMurNAc). The reaction was monitored on a $\mathrm{C}_{18}$ reversed-phase HPLC column (Symmetry Shield RP18, $5 \mu \mathrm{m}, 3.9 \mathrm{~mm}$ by $150 \mathrm{~mm}$; Waters) on a PerkinElmer series 200 System. The column was equilibrated with $0.05 \%$ trifluoroacetic acid in water and eluted with a linear acetonitrile gradient from 0 to $15 \%$ over $40 \mathrm{~min}$ with a flow rate of $1 \mathrm{~mL} / \mathrm{min}$. The column effluent was monitored at $205 \mathrm{~nm}$. 

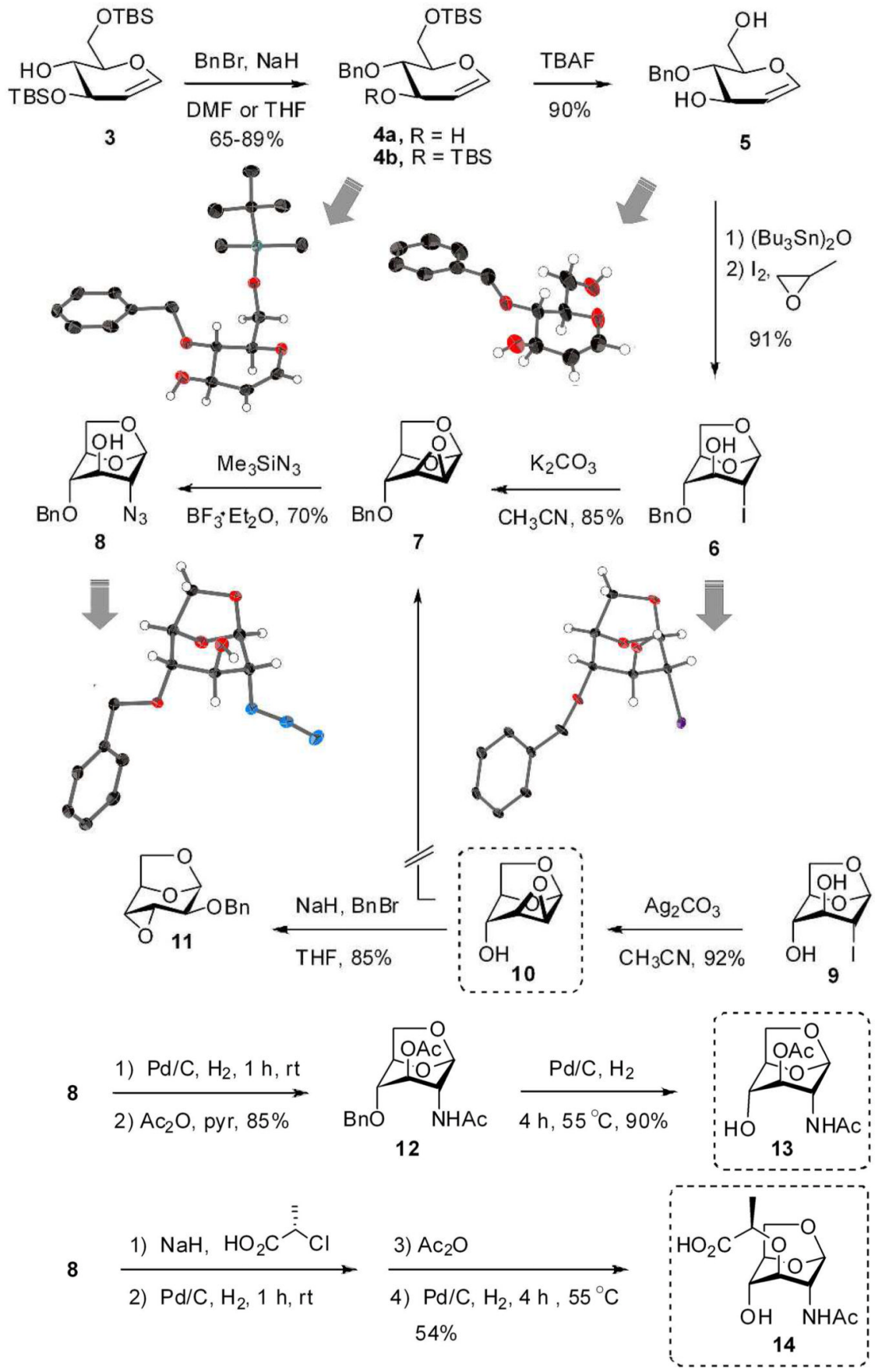

Scheme 1.

Synthesis of glycosyl acceptors (boxed). The thick gray arrows link the chemical structures to the ORTEP diagrams (50\% probability) for the intermediates that were amenable to X-ray structure determination. The ORTEP diagrams are given in Supporting Information as well. 


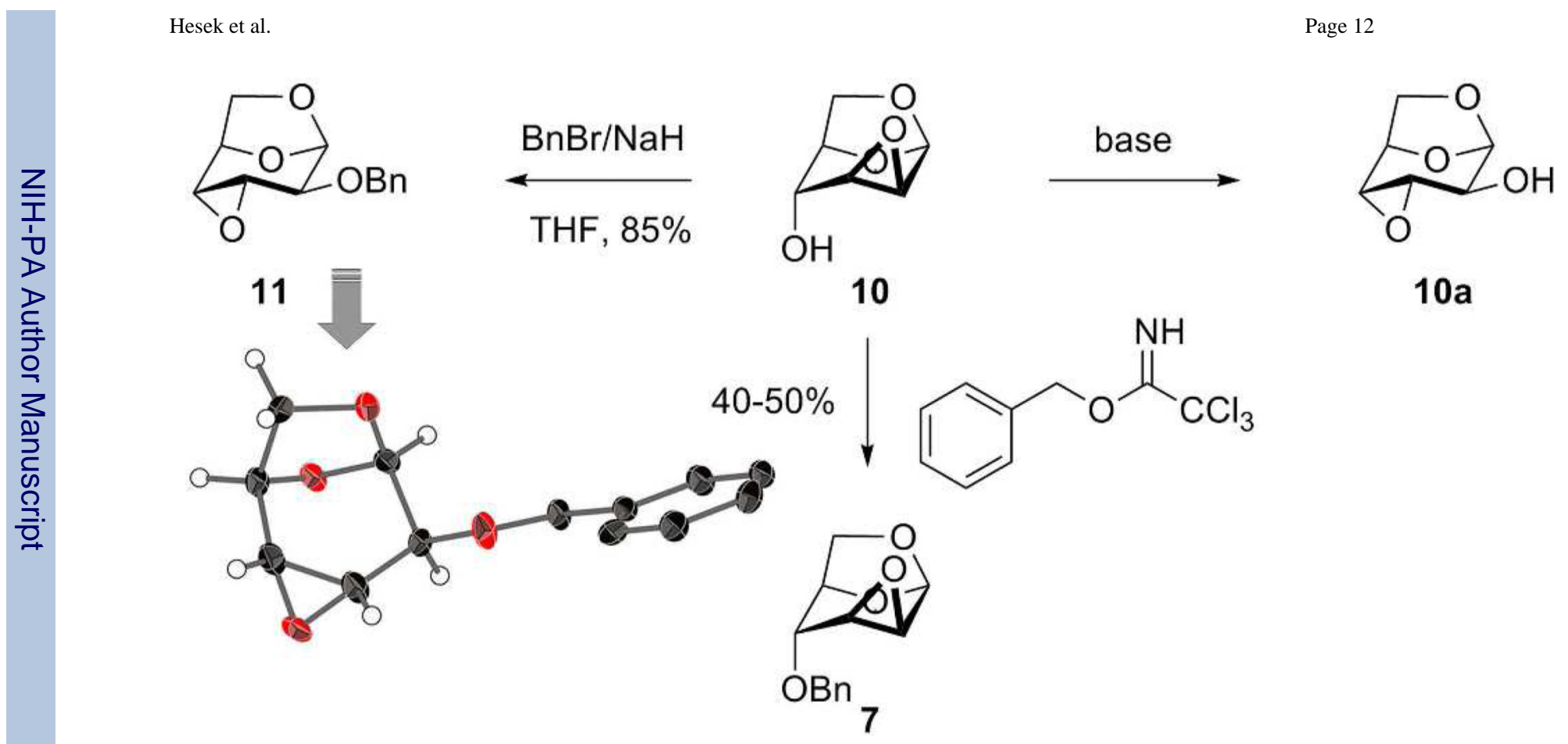

Scheme 2.

Payne rearrangement of epoxide $\mathbf{1 0}$ and an alternative to $\mathbf{7 .}$ 
(A)

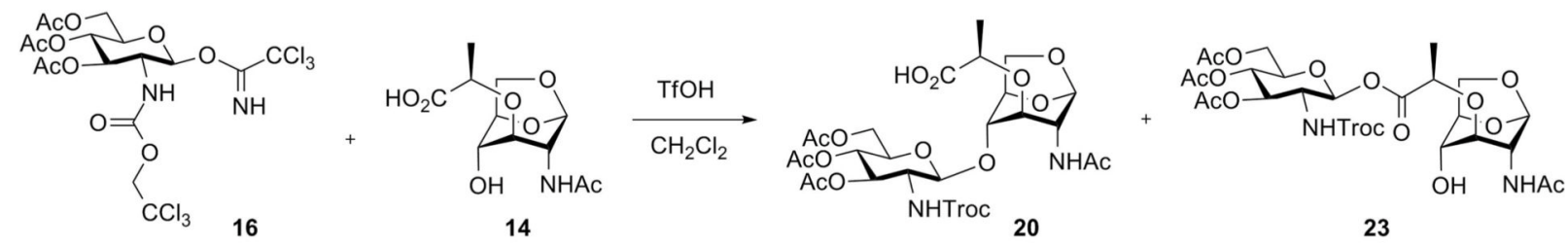

(B)

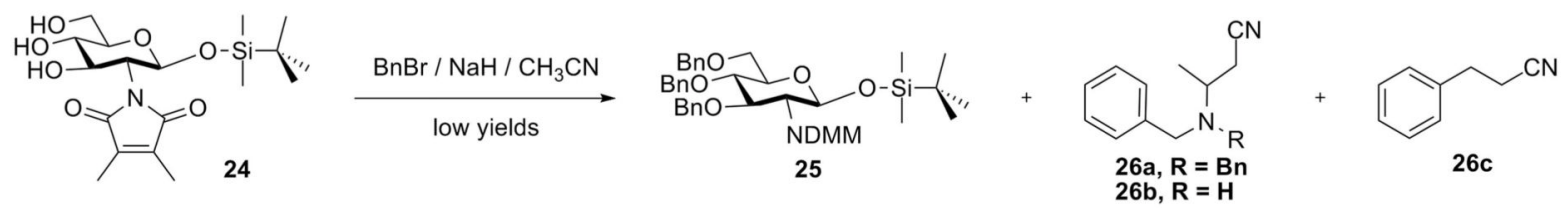

(C)

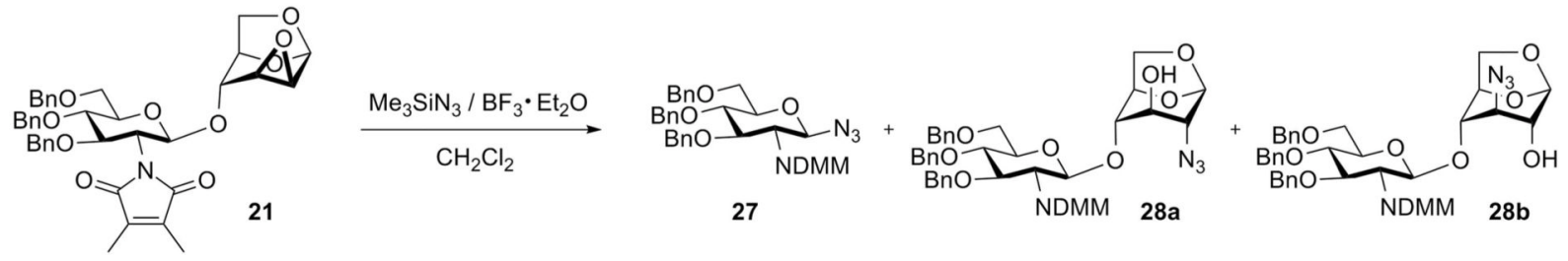

(D)

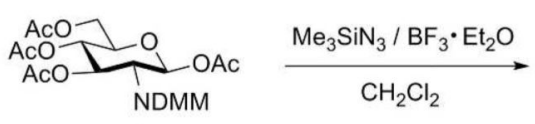

29

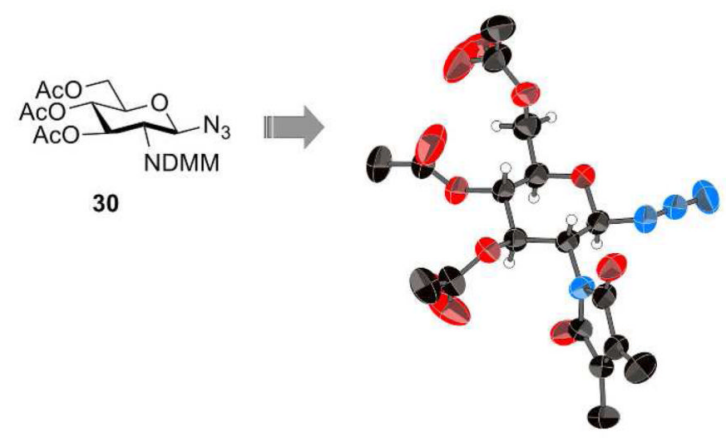

Scheme 3.

Glycosylation attempts 

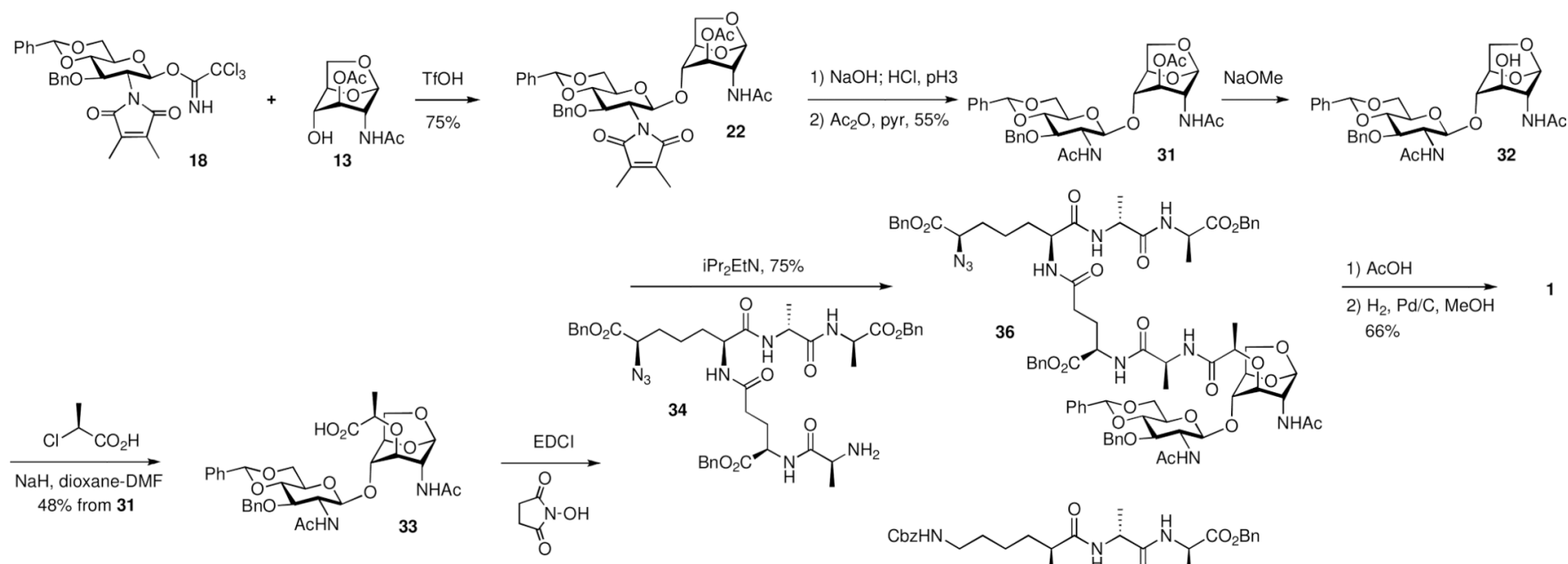

34

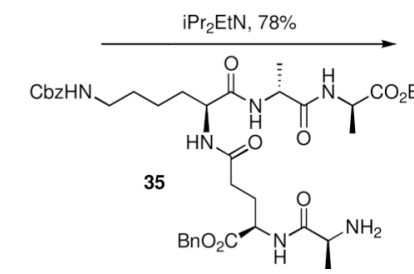<smiles>CC(NC(=O)[C@H](C)NC(=O)C(CCCC(N)C(=O)O)NC=O)C(=O)OCc1ccccc1</smiles>
$\underset{\text { 1) } \mathrm{AcOH}}{\stackrel{\mathrm{H}_{2}, \mathrm{Pd} / \mathrm{C}, \mathrm{MeOH}}{66 \%}}$
1

36

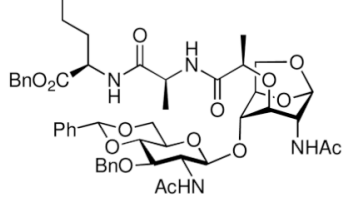

37<smiles>CC(NC(=O)[C@H](C)NC(=O)Cc1ccccc1)C(=O)NC(C)C(=O)OCc1ccccc1</smiles>

$64 \%$

Scheme 4.

Completion of the synthesis 